石油技術協会誌 第 78 巻 第 1 号 （平成 25 年 1 月） $47 \sim 55$ 頁

Journal of the Japanese Association for Petroleum Technology

Vol. 78, No. 1 (Jan., 2013) pp. 47 55

講 演

Lecture

\title{
Using technology to evaluate and optimize unconventional resource development*
}

\author{
Mike Zuber ${ }^{* *}$
}

(Received September 21, 2012 : accepted February 4, 2013)

\begin{abstract}
Organic shales are complex reservoirs, and they present many challenges to achieving commercial development, including: identifying, mapping and staying within sweet spots, determining well locations and spacing, optimizing drilling, enhancing completion and stimulation strategies, identifying operational efficiencies, and at the same time respecting environmental sensitivities and regulatory issues. All unconventional plays are unique. What works well in one play may not translate well to another.

There are a wide variety of technologies that are utilized in the finding, evaluation, drilling, completion and production of hydrocarbons from shale reservoirs. Experience from North American shale development shows that technologies that have the greatest impact on the commercial success of shale development are those that contribute to finding the best places to drill and complete wells and/or those that make it more efficient and less costly to develop and produce hydrocarbons. Careful selection of technology and services is essential for long-term success, confident decisions, and improving operational efficiency. Continuously refining techniques drives improved economics.

The purpose of this paper is to discuss and demonstrate how various technologies have contributed to the commercial development of hydrocarbons from organic shale reservoirs.
\end{abstract}

Keywords : shale, unconventional hydrocarbon, technology, optimization, North America

\section{Introduction}

Unconventional shale resources have been in the limelight for several years in North America, and interest in shale resources has increased significantly in the international environment. As we move to the international market, technology will play an even larger role in the exploration, appraisal, and development of unconventional resources worldwide. The focus of this paper is to highlight the role technology will play in the future in unleashing the full potential of the shale resources.

Organic shales are complex reservoirs ${ }^{1)}$, , and they present many challenges to achieving commercial development, including: identifying, mapping and staying within sweet spots, determining well locations and spacing, optimizing drilling, enhancing completion and stimulation strategies, identifying operational efficiencies, and at the same time respecting environmental sensitivities and regulatory issues. ${ }^{4{ }^{4-9}}$ All unconventional plays are unique. What works well in one play may not translate well to another.

There are a wide variety of technologies that are utilized in the finding, evaluation, drilling, completion and production

\footnotetext{
*平成 24 年 6 月 6 日, 平成 24 年石油技術協会春季講演会, 地質・探鉱 部門シンポジウム「シェールロックのジオサイエンス」にて講演 This paper was presented at the 2012 JAPT Geology and Exploration Symposium ***ュルンベルジェ(株) Schlumberger
}

of hydrocarbons from shale reservoirs. Experience from North American shale development shows that technologies that have the greatest impact on the commercial success of shale development are those that contribute to finding the best places to drill and complete wells and/or those that make it more efficient and less costly to develop and produce hydrocarbons. Careful selection of technology and services is essential for long-term success, confident decisions, and improving operational efficiency. Continuously refining techniques drives improved economics.

The purpose of this paper is to discuss and demonstrate how various technologies have contributed to the commercial development of hydrocarbons from organic shale reservoirs. A number of case histories from mature and developing shale plays are referenced as examples of how technology facilitates commercial development of shale plays.

\section{The Nature of Organic Shale Reservoirs}

\subsection{Reservoir Complexity}

Organic shale reservoirs are all fine-grained, argillaceous sediment containing mud, clay, and mudstone, as well as organic material ${ }^{12)}$. Because of their fine-grained nature, all organic shale reservoirs are complex, extremely lowpermeability formations. The hydrocarbon storage and flow mechanisms in organic shale reservoirs are complex, as 
indicated in Fig. 1. ${ }^{3)}$ Gas is stored in the organic shale in both free porosity, as well as the adsorbed state. Gas must flow first through a very fine-grained and low-permeability matrix to the natural fracture system. Producing wells drilled in organic shales are completed using hydraulic fractures, which serve to connect the wellbore to the natural fracture system. The ability to effectively connect the wellbore to the natural fracture system is a key element of commercial organic shale development projects.

Because of how organic sales are deposited, organic shales are typically extensive (thousands of square miles) and very thick deposits $(>50-500 \mathrm{ft}$ thick). Shales tend to be highly variable (laminated) from a mineralogical standpoint within the vertical pay section. ${ }^{1)}{ }^{2,}{ }^{12)}$ Variations in mineralogy and other reservoir properties create complexity in terms of reservoir quality and completion quality, and must be quantified and understood in order to correctly assess productivity potential.

Because of the complexity of shale reservoirs, a comprehensive integrated-evaluation approach must be undertaken to understand and evaluate the productivity potential of a particular shale play or project. ${ }^{12)}$ In particular, we must determine the various parameters which are responsible for the reservoir quality and the completion quality of a shale reservoir. The parameters that make up reservoir quality and completion quality are shown below.

\section{Controls on Reservoir Productivity}

Defining Reservoir Quality (RQ)

- Oil / Gas in place

- Porosity

- Permeability

- TOC and Maturation

- Pore Pressure

Defining Completion Quality (CQ)

- Fracture Containment (anisotropy, in-situ stress)

- Rock mechanics (surface area per reservoir volume)

- Ability to retain surface area

- Fracture conductivity

\section{- Fluid sensitivity}

Reservoir quality is primarily related to those parameters which contribute to the volume of hydrocarbon in place, as well as permeability. Completion quality pertains to those factors which contribute to the ease at which hydraulic fractures can be created within the shale formation, as well as the containment and preservation of hydraulic fractures. As such, the understanding of the magnitude and orientation of stress within the shale formation is extremely important to understand and quantify. Other factors such as the tendency for proppant embedment and proppant crushing must be considered. In addition, potential interactions between hydraulic fracturing fluids and the formation are also important to understand and build into the hydraulic fracture fluid design.

\subsection{Commercial Complexity}

Because organic shale deposits are very extensive, and developing shale projects have hundreds to thousands of wells and well locations, land-use, resource utilization, and environmental concerns are important aspects of large-scale shale development projects. Because of these concerns and characteristics, field development planning, logistical planning and execution, and operational efficiency are all important aspects of developing shale projects.

Beyond the need to have good reservoir and completion quality, there are a number of external and/or commercial factors that control the viability of organic shale project development. These include the following.

- Availability of required services and workforce.

- Available gas market and acceptable hydrocarbon prices.

- Favorable government regulatory regime.

- Favorable environmental regulatory framework.

- Available infrastructure.

- Ability to acquire acreage for development.

\section{North American Experience}

\subsection{Transformation}

The development of gas and oil shale's in the United States

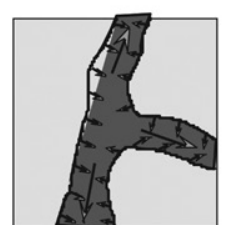

How through fractures

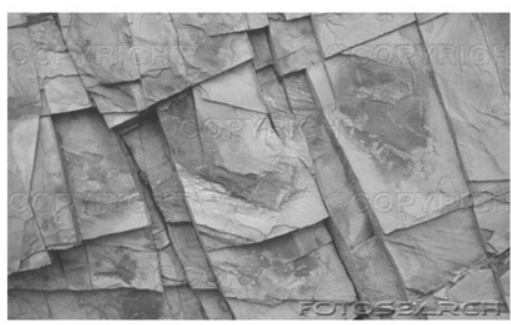

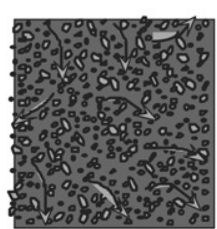

How through matrix

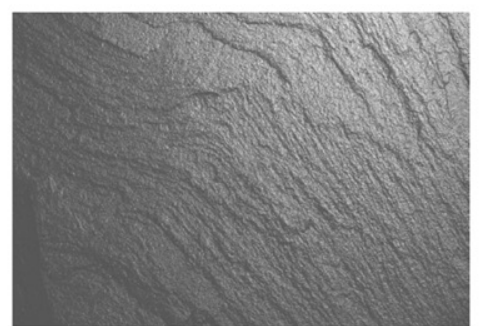

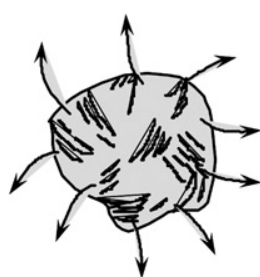

Desorption from kerogen

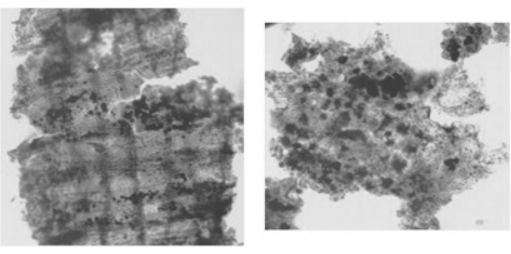

Fig. 1 Storage and flow mechanisms in organic shale reservoirs. 
has truly transformed the US gas industry. Fig. 2 shows that in 2000 only three shale plays in the United States had undergone significant development. By 2010, more than 15 shale plays had undergone significant development and more than 7000 wells had been drilled in shale plays in the US. The boom in shale development in this period of time was due to many factors, including the development of specialized technologies for exploiting shale reservoirs (primarily horizontal laterals with multiple, transverse hydraulic fractures), strong gas and oil prices, a favorable regulatory regime, the availability of services, and existing infrastructure.

\subsection{Challenges Identified}

Because of the extensive development of shale resources in North America in the past decade, a large data set has been generated, which allows us to evaluate and understand the challenges associated with shale project development. Evaluation of data from these emerging and mature projects in north
America provides insights into the challenges for developing shale projects. One of the challenges associated with shale reservoirs is that every reservoir is different. ${ }^{1,2), 12)}$ Each play is unique in terms of the reservoir make up, and the technologies and solutions which can be used to optimize development. Fig. 3 shows the lithological composition up of three commercial shale plays. ${ }^{12)}$ Each is different in terms of the litholigical components which make up of the organic shale reservoir, yet each is a viable commercial play. Each shale play has its own "formula", in terms of exploitation technologies and solutions which must be determined through understanding the nature of the reservoir and determining which technologies are appropriate.

Valuable insights can also be gained by evaluating the historical production performance from mature shale plays. 4 Fig. 4 and 5 show well drilling statistics and production statistics for the Barnett shale play for the period from 1983 through 2009. Fig. 5 shows the number of vertical, deviated,
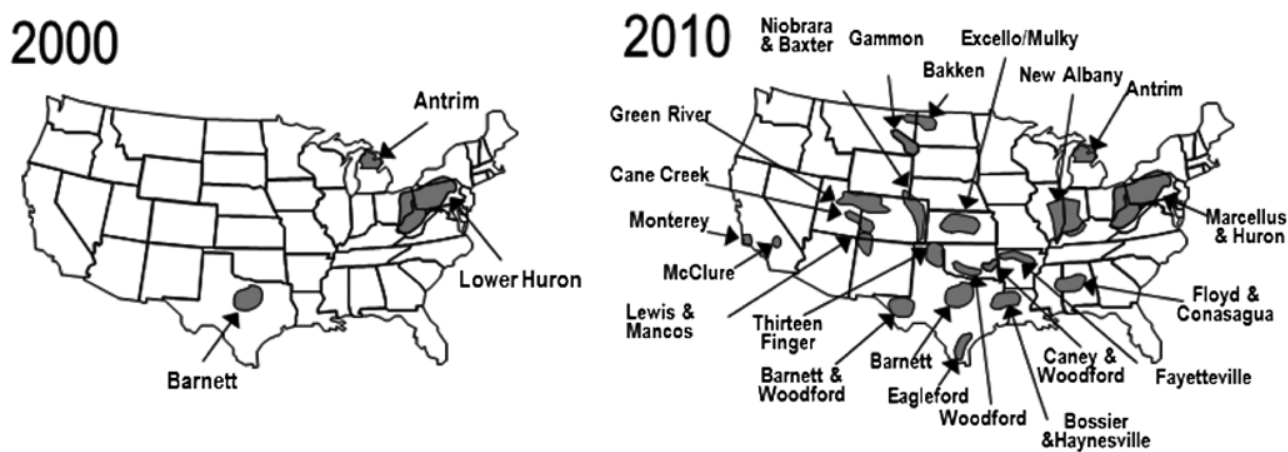

Fig. 2 Basins with significant organic shale projects: $2000-2010$.

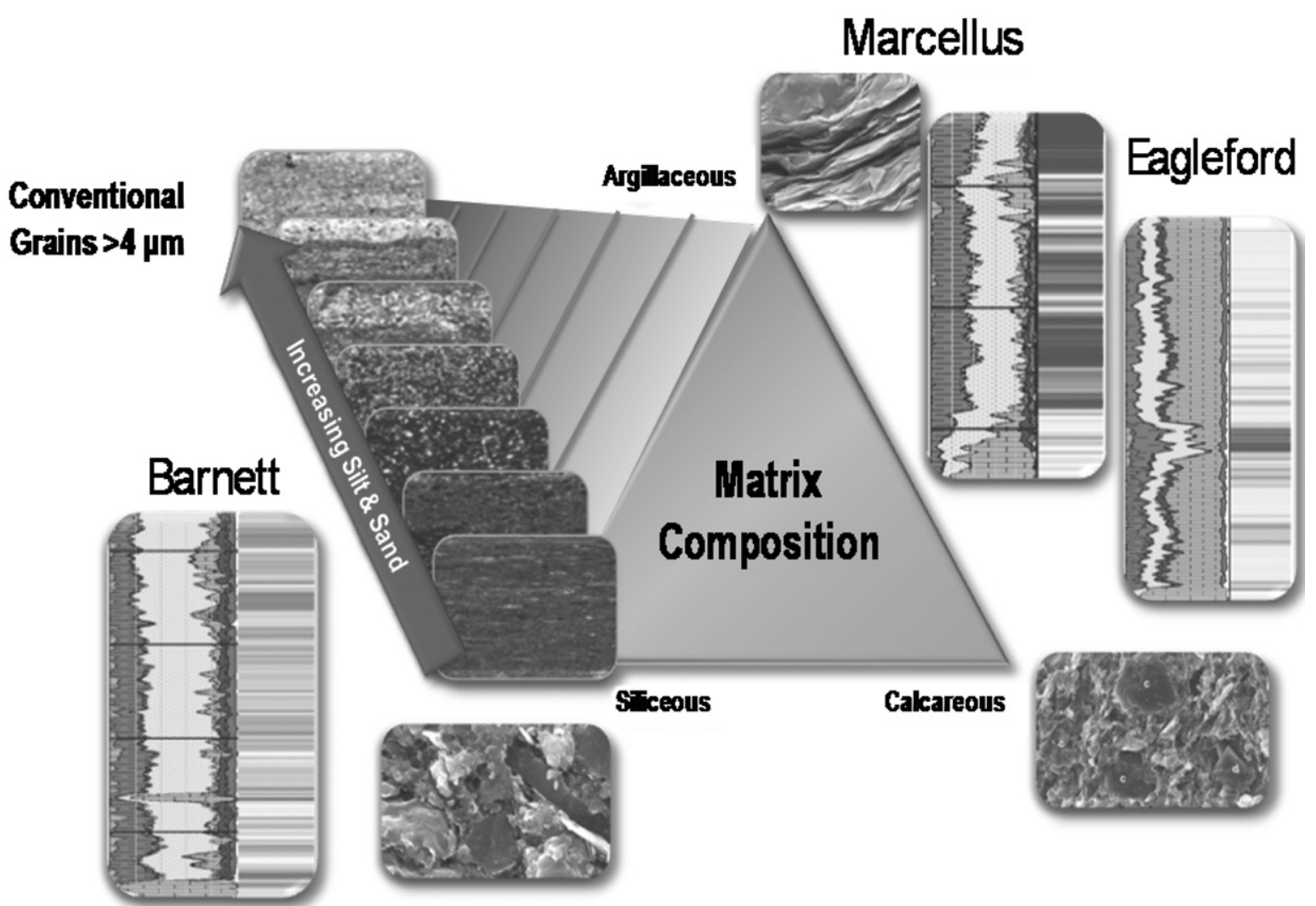

Fig. 3 Variability in matrix composition for three commercial shale plays. 


\section{Month Cumulative Production}

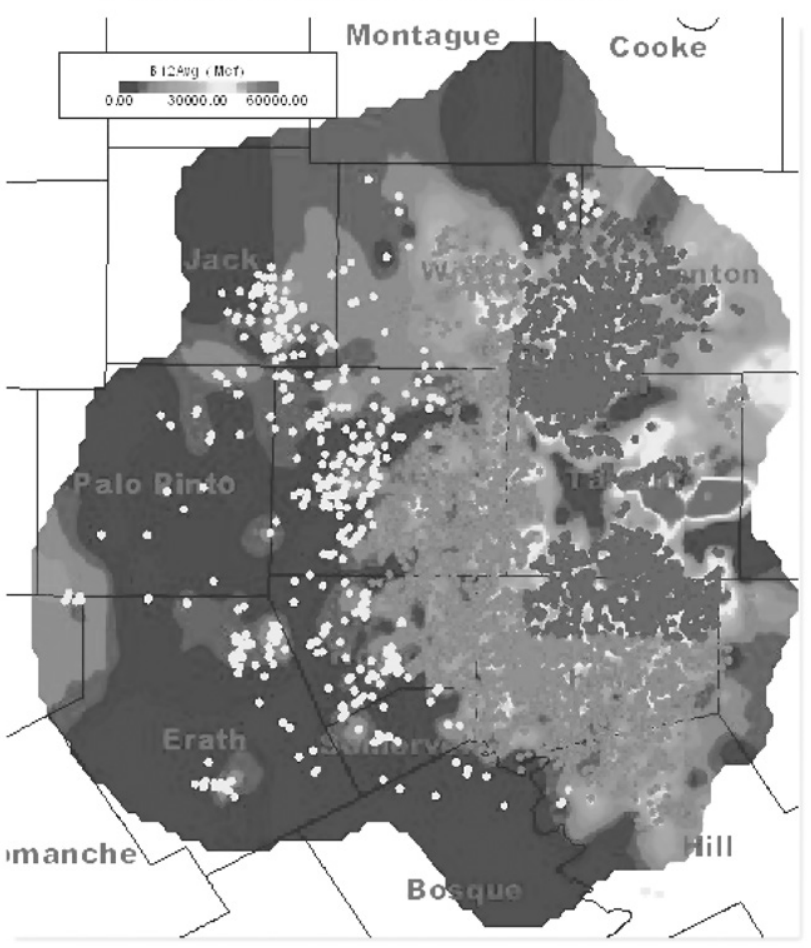

Fig. 4 Dot map of first 3-month cumulative gas production for the Barnett Shale play indicating sweet spots at the basin scale. ${ }^{10)}$ or horizontal wells drilled by quarter during this time, as well as, the first 12-months of production by well for each well. Fig. 4 is a map indicating the first three-months of production by well across the basin. These graphics illustrate one of the key challenges to developing shale plays. Fig. 4 shows that there are definite sweet spots within the Barnett play, where production is significantly better than other parts of the basin. Evaluation of geological and reservoir data indicate that the sweet spots are generally associated with parts of the play containing the highest gas in place potential. However, variations in production on the scale of one order of magnitude are observed down to the field scale. Given that sweet spots will exist in every shale play, one of the challenges in emerging and new shale plays is the early identification of sweet spots. Early identification of sweet spot areas will improve economic returns and accelerate development of emerging shale plays. Technologies which can assist and identification of basin sweet spots will prove extremely valuable in promoting development of shale plays in the international market.

An additional challenge to shale development is the understanding of individual well performance. Fig. 5 shows the peak gas rate associated with individual shale wells drilled in the Barnett shale over time. In the period from 2004 through 2009, essentially all wells drilled were horizontal wells
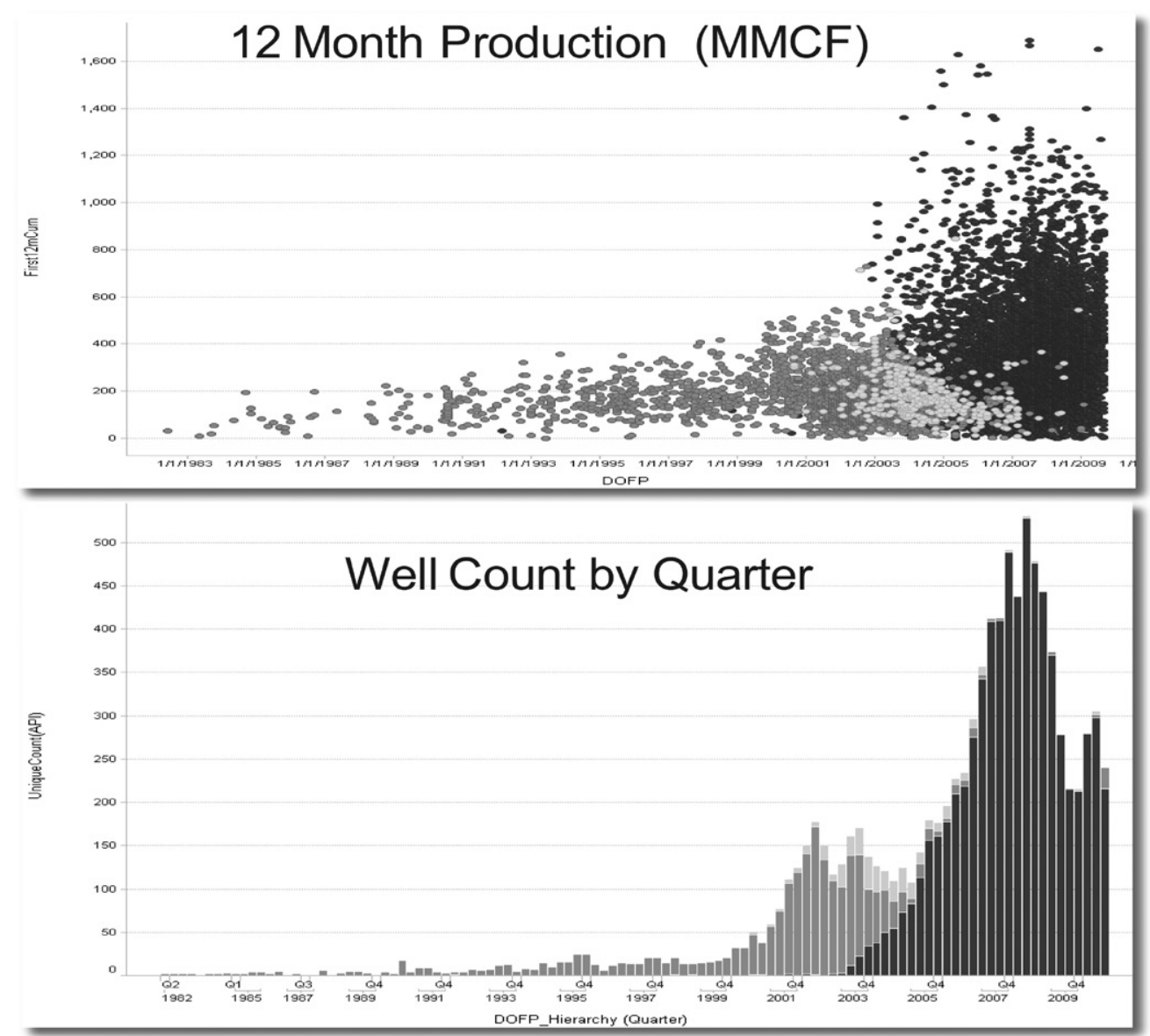

Fig. 5 Development history of the Barnett Shale play (1982-2009). Red bar and dots are vertical wells, orange are deviated wells and blue are horizontal wells. ${ }^{10)}$ 
with multiple hydraulic fractures. This plot demonstrates the high degree of variability in well performance for horizontal Barnett wells during drill during this time. While the development of horizontal well technology for shale wells improved the potential for production from the Barnett shale, there were still many sub economic wells drilled in the Barnett play during this time. The reason for the low performance of these horizontal multilateral wells can only be understood if appropriate data are available to indicate the connection between production performance and reservoir and completion quality. ${ }^{72}{ }^{12)}$ In most instances in the Barnett play, appropriate data acquisition was not performed, so the determination of the causes of low well performance is difficult or impossible.

Based on the development of numerous organic shales in North America in the previous decade, a number of challenges to optimizing production, reserves, and economic returns from shale development projects have been identified. A number of these important challenges are listed below.

- Production performance is highly variable, down to the field scale.

- Sweet spots (areas of better than average quality) exist (1) at the basin scale, (2) at the field scale, (3) vertically within the shale interval, and (4) laterally along a horizontal lateral.

- In horizontal wells completed with multiple hydraulic fracture stages uniformly spaced along the lateral, a significant number of perforation clusters and hydraulic fracture stages are not producing or essentially nonproductive.
- Lack of data acquisition and formation evaluation limits the ability to critique production performance and optimize development strategies.

- Development efficiency is important for optimizing economic returns:

- Time to drill horizontal lateral

- Time required to complete and stimulate

- Logistical economies of scale

- The scale and pace of developing projects requires efficient use of land, water and other resources.

\section{Enabling Technologies}

There are a wide variety of technologies that are utilized in the finding, evaluation, drilling, completion and production of hydrocarbons from shale reservoirs. Experience from North American shale development shows that technologies that have the greatest impact on the commercial success of shale development are those that contribute to finding the best places to drill and complete wells and/or those that make it more efficient and less costly to develop and produce hydrocarbons (see Fig. 6).

Technologies that relate to evaluation of shale reservoirs provide for the determination of reservoir quality and completion quality, identifying sweet spots within the reservoir and within a developing field, provide the ability to understand existing production performance, and provide input into the field development process. Technologies which apply to well drilling generally focus on improved efficiency in the drilling process. The cost to drill wells is strongly related to time. The cost to drill a well is equivalent to the daily rig rate times the
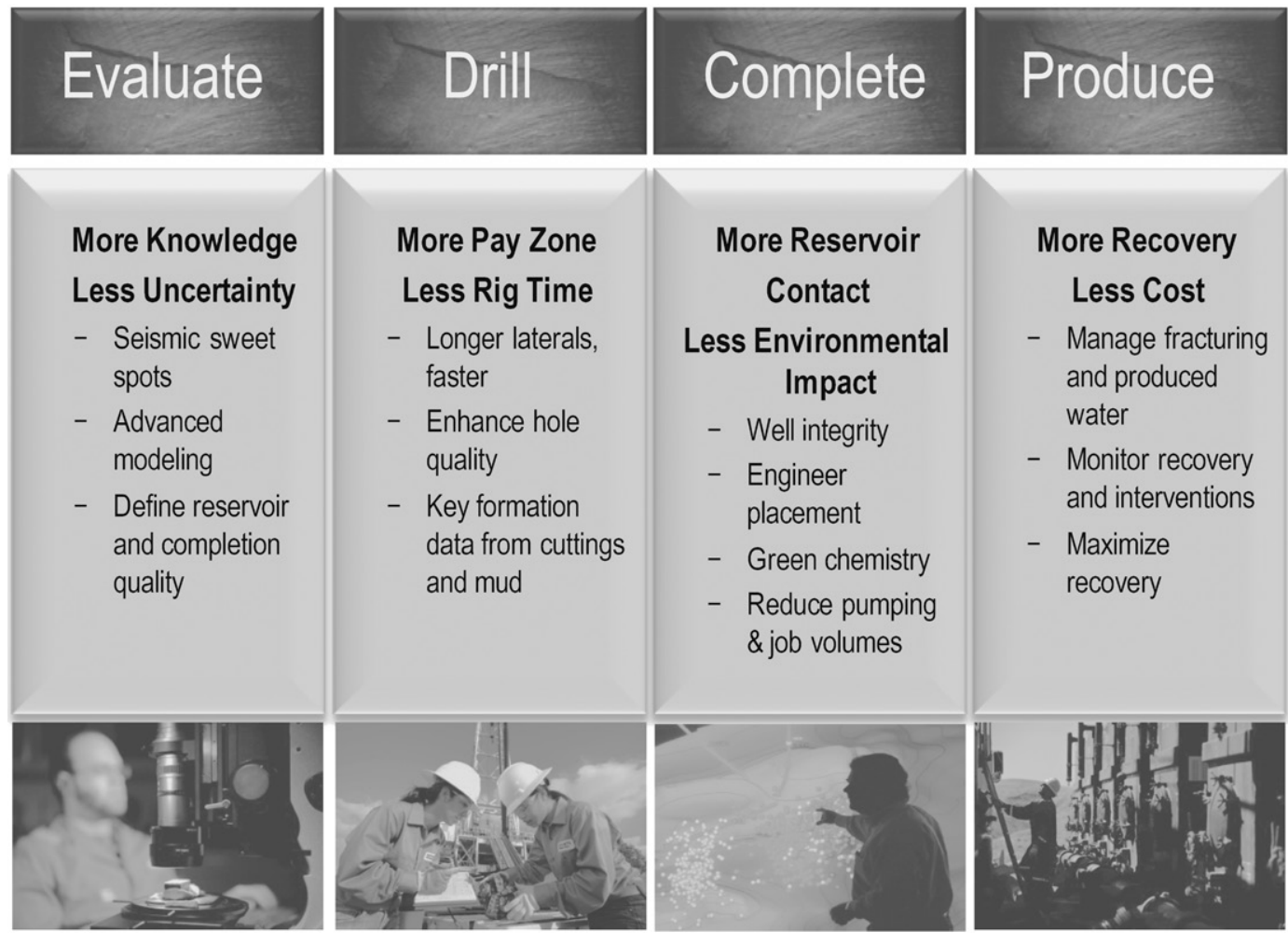

Fig. 6 Technologies that enable successful organic shale development target key stages of the development process. 
number of days it takes to drill a well and horizontal lateral. Any improvements in technology that reduce the time to drill the well provide significant reductions in well cost. The ultimate goal is to drill the longest possible horizontal lateral as quickly as possible. Key technologies that allow this to be accomplished relate to bit technologies, mud technology and directional drilling (geo-steering) technologies. In addition, key data can be obtained from measurement while drilling (MWD) and logging while drilling (LWD) technologies. ${ }^{7)}$

Technologies related to the well completion provide for efficiencies in the hydraulic fracturing process. Micro-seismic monitoring has proven to be a key technology in developing shale reservoirs for understanding the effectiveness of hydraulic fracture treatments and optimizing the hydraulic fracture design.5 Technologies that allow faster placement of multiple hydraulic fractures along the lateral provide significant reductions in well cost. Technologies relating to the placement of the well within the desired interval within the shale section are also significant in terms of providing optimized well completions and the maximum production and reserves. ${ }^{6)}$

There are a number of technologies which apply to the production and management of production from shale wells. An important aspect of shale well production is the production, treatment and disposal of produced waters. A number of technologies are available which allow produced waters to be treated and disposed in an environmentally friendly way. New technologies will continue to be developed which will reduce the cost of treatment and disposal of produced waters. Monitoring of shale well production is also an important aspect of the production process. Understanding production performance from well-to-well, and across producing field areas is important for planning future field development activities, as well as work-over and production enhancement operations. Technologies which provide data as to the production of individual perforation and hydraulic fracture stages along the horizontal lateral are important for understanding well performance and designing remedial work-over treatments.

Because of the complexity of shale reservoirs and the high number of wells drilled in developing shale projects, one characteristic of these projects is the large volume of data generated. A wide variety of data is generated in these projects, including seismic (most mature projects have 3D seismic), core data, well log data, geo-mechanical data, well drilling and completion data, as well as production data. Technologies that allow geoscientists and managers to integrate and assess large amounts of these data are important for optimal management and planning of developing shale projects. ${ }^{8)-10)}$

One example of how integration of various types of data are useful for understanding and evaluating shale reservoirs is shown in Fig. 7. This figure depicts the formation evaluation workflow that is typically applied to exploration wells drilled in early-stage development of shale projects. ${ }^{7,11,)}{ }^{12}$ ) The main objective of these wells (vertical wells) is to understand the shale reservoir lithology, quantify gas and oil in place, identify sweet spots within the pay interval, and provide information relating to completion quality. This workflow involves integration of specialized logs, specialized core tests, and specialized geo-mechanical test run on cores, as well as

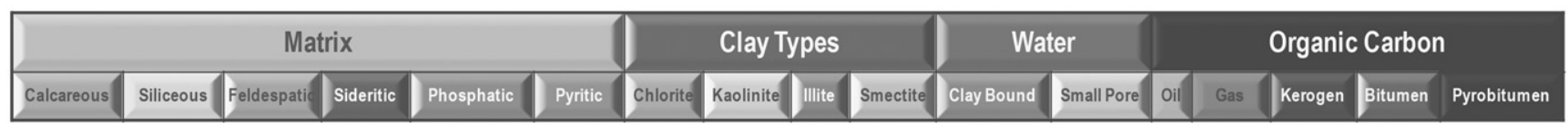

Petrology

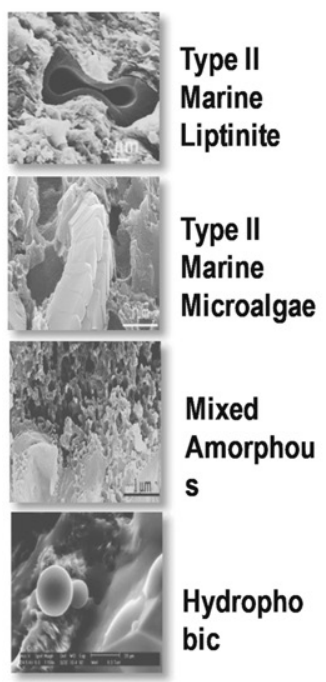

Logs

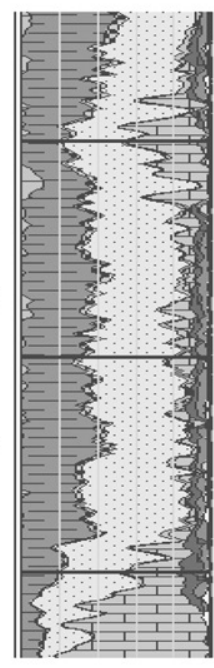

Geomechanics Stress
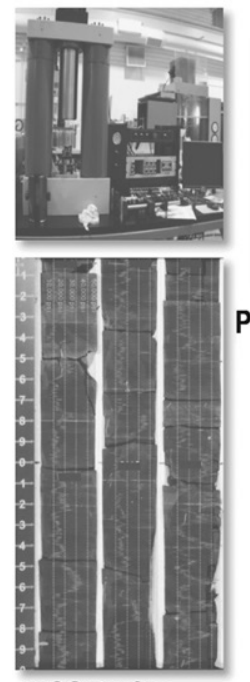

UCS Profile
Fluid Sensitivity Fracture Conductivity

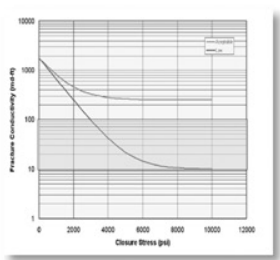

Proppant Embedment in Argillaceous Shale

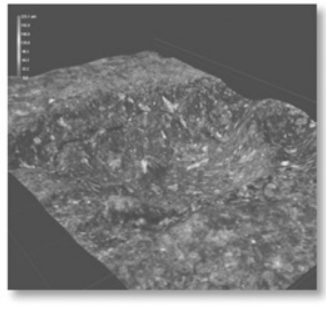

Core to Log Integration

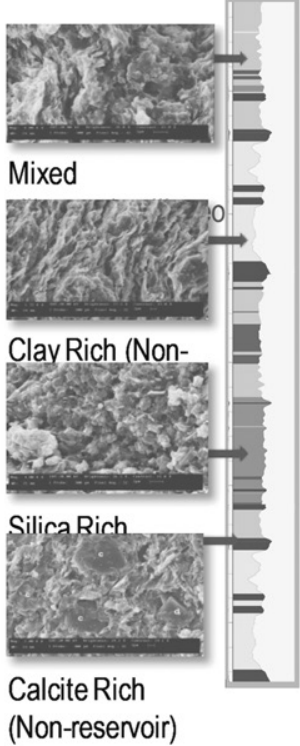

Fig. 7 Example of formation evaluation workflow for shale reservoirs - integration of log, core and geomechanical information provides a comprehensive understanding of reservoir quality and completion quality. 
stress tests performed in the field. Through integration of all of these data from various formation evaluation methods, we gain an understanding and quantification of the quality of the shale reservoir, determine variations of key properties within the shale section, and quantify completion quality, which provides valuable information for the design of hydraulic fracture treatments.

Fig. 8 illustrates the variety of technologies which are involved in developing shale projects. The figure illustrated key technologies associated with two workflows: (1) the well design evaluation and development process and (2) the field development planning evaluation process. Design, execution and evaluation of shale wells uses technologies to understand the shale interval, and technologies to design the well (well placement within the vertical section as well as the design of the hydraulic fracture treatments). An important aspect of the hydraulic fracture design is the placement of perforated intervals along the horizontal lateral and the fluids, proppant, and treating volumes and rates of the hydraulic fracture treatment. Technologies used to diagnose the performance of the hydraulic fracturing process are also a key aspect of shale projects. These include micro seismic monitoring and mapping, production logging, tracer technologies, and hydraulic fracture modeling. Once a well is drilled, completed, and placed online, evaluation of production data is a key aspect of evaluating well performance and critiquing the performance of the completion design. Shale-specific reservoir simulation models are used for this purpose to history match well production performance, understand the relationship between reservoir properties and well performance, and evaluate the effectiveness of the well and completion design. ${ }^{1), 3), 9)}$

A key aspect of effective management of developing shale projects is the integration of all available field data. This involves construction of living models and databases which store all available field data, including seismic (most fields in North America have 3-D seismic), core and well log data and interpretations, production data, well drilling and completion records, completion diagnostic data (such as microseismic), geo-mechanical information and test results. ${ }^{9}$ Once a significant number of wells are drilled in a developing play or project it is common to attempt to correlate observed production performance with 3-D seismic attributes. ${ }^{9)}$ Seismic attributes can easily be extrapolated across the field, therefore, if reservoir performance (good or bad) can be linked to seismic attributes, or a combination of seismic attributes, then this information can be extremely useful in planning locations for future development wells and optimizing the field development performance.

\section{Summary}

Technology will continue to play an important role in developing unconventional gas projects. In unconventional

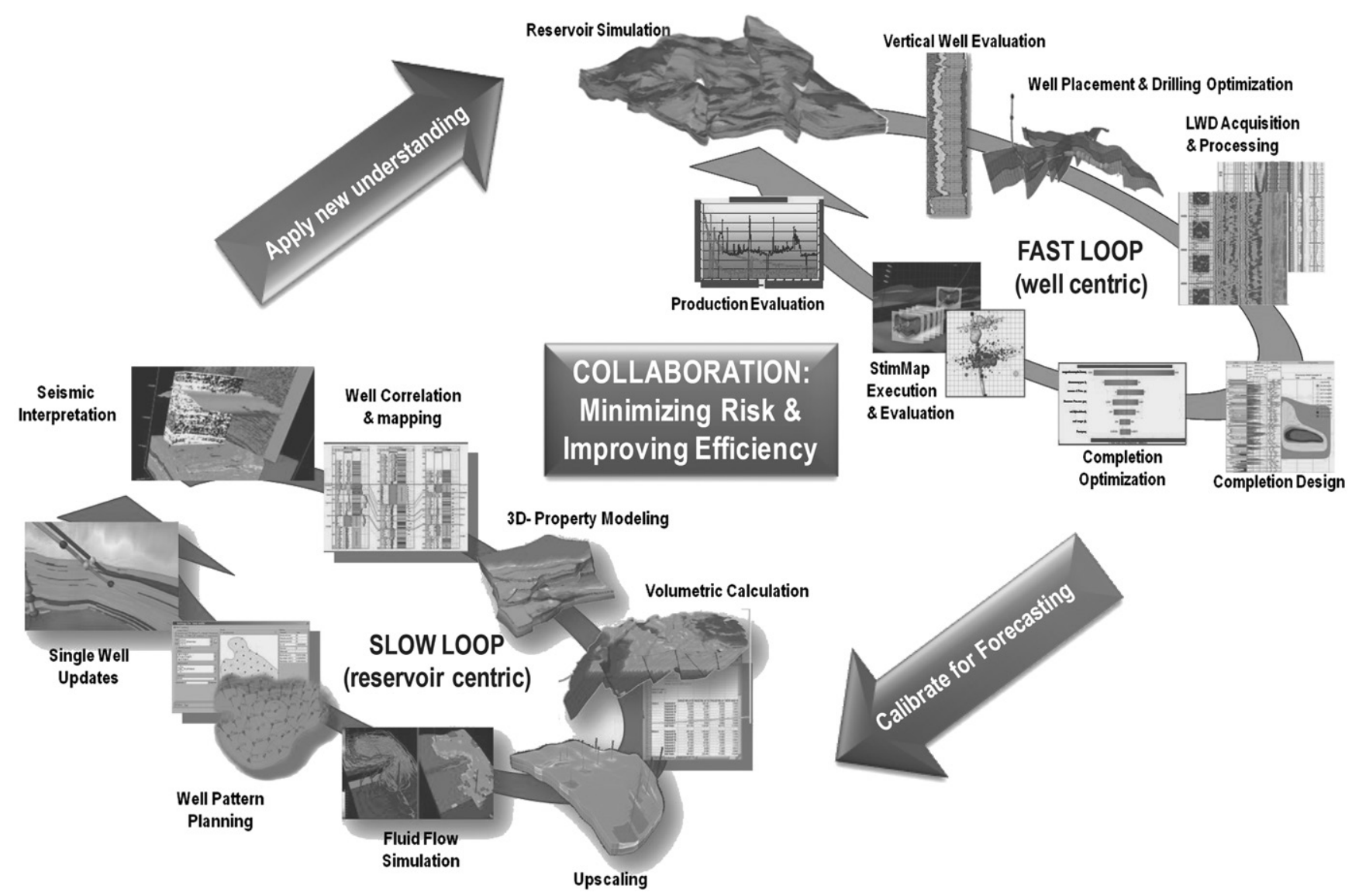

Fig. 8 High-level workflows for (1) well planning, execution and evaluation and (2) field development planning and monitoring. ${ }^{9)}$ 


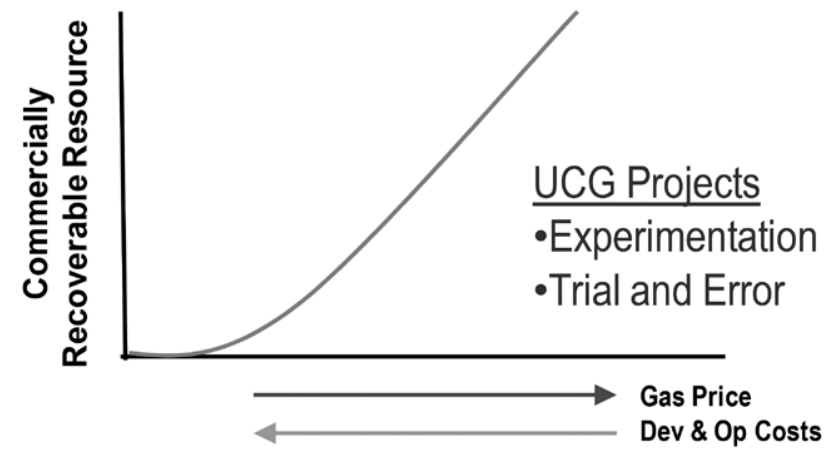

Fig. 9 Relationship between recoverable unconventional resources, commodity price, and development costs.

projects, there is a strong relationship between the amount of commercially recoverable resource and the cost of development and commodity prices, as indicated in Fig. 9. Commercial development of unconventional projects will always be highly dependent upon commodity prices. In the period from 2000 2010, when gas prices were high in north America, massive investments were made to develop unconventional gas and oil projects. The role of technology in the development of unconventional resources is to effectively minimize and reduce development and operating costs. Operators and service companies will continue to strive to develop technologies that reduce the cost to develop unconventional resources, and maximize production and recovery of reserves.

Development of unconventional gas and oil projects involves a continual optimization process. The generalized optimization process is shown below. The process generally involves some initial development or field activity. A key aspect of the process is data acquisition - gathering of measurements, samples, or field data, which are then evaluated him in some critical manner. The results of the evaluation are then used to make decisions regarding future developments, and make changes designed to optimize future developments.

Generalized Optimization Process

- Develop

- Measure / Sample / Gather Data

- Evaluate Data (Analysis)

- Decide / Optimize

Developing unconventional gas projects generally follow four stages of development, has shown below. The optimization process is important at all stages of developing projects. In effect, unconventional projects involve a continuous learning, experimenting, and optimization process.

The "Stages" of Optimization in an Unconventional Gas Project

- Exploration

- Pilot

- Early Development

- Mature Development

Experience from North American shale development shows that technologies that have the greatest impact on the commercial success of shale development are those that contribute to finding the best places to drill and complete wells and/or those that make it more efficient and less costly to develop and produce hydrocarbons. Careful selection of technology and services is essential for long-term success, confident decisions, and improving operational efficiency. Continuously refining techniques drives improved economics.

\section{References}

1) J.H. Frantz, Jr., J.R. Williamson, W.K. Sawyer, D. Johnston, G. Waters, L.P. Moore, R.J. MacDonald, M. Pearcy, S.V. Ganpule and K.S. March, 2005 : Evaluating Barnett Shale Production Performance-Using an Integrated Approach. Conference Paper SPE 96917-MS presented at the 2005 SPE Annual Technical Conference and Exhibition, Dallas, Texas, USA, 9-12 October.

2) Jenkins, C.D. and Boyer II, C.M., 2008 : Coalbed- and Shale-Gas Reservoirs. Journal of Petroleum Technology, 60 (2) ,92-199.

3) Du, C.M., Lang Zhan, James Li, Xu Zhang, Stefen Church, K. Tushingham and Brad Hay, 2011: Generalization of Dual-Porosity-System Representation and Reservoir Simulation of Hydraulic Fracturing-Stimulated Shale Gas Reservoirs. Conference Paper SPE 146534 presented at the SPE Annual Technical Conference and Exhibition, 30 October-2 November 2011, Denver, Colorado, USA.

4) Baihly, Jason, R. Altman, Raj Malpani and Fang Luo, 2010 : Shale Gas Production Decline Trend Comparison over Time and Basins. Conference Paper SPE 135555 presented at the SPE Annual Technical Conference and Exhibition, 19-22 September 2010, Florence, Italy.

5) Cipolla, C.L., M. J. Williams, X. Weng, M. Mack and S. Maxwell, 2010 : Hydraulic Fracture Monitoring to Reservoir Simulation: Maximizing Value. Conference Paper SPE 133877 presented at the SPE Annual Technical Conference and Exhibition, 19-22 September 2010, Florence, Italy.

6) Kok, Jeffrey, B. Moon, Shim Yen Han, E. Tollefsen, J. Baihly and Raj Malpani, 2010 : The Significance of Accurate Well Placement in the Shale Gas Play. Conference Paper SPE 138438 presented at the SPE Tight Gas Completions Conference, 2-3 November 2010, San Antonio, Texas, USA.

7) Baihly, J.D., R. Malpani, C. Edwards, S. Y. Han, J. C. L. Kok, E. Tollefsen and C. W. Wheeler, 2010 : Unlocking the Shale Mystery: How Lateral Measurements and Well Placement Impact Completions and Resultant Production. Conference Paper SPE 138427 presented at the SPE Tight Gas Completions Conference, 2-3 November 2010, San Antonio, Texas, USA.

8) Ibrahim, Hani, Yashodhan Gidh, and Arifin Purwanto, 2011 : Holistic Optimization Approach Improves Economic Viability of Bakken Shale Play. Conference Paper SPE 142878 presented at the SPE Digital Energy Conference and Exhibition, 19-21 April 2011, The Woodlands, Texas, USA.

9) Ramakrishnan, Hariharan, Eva Peza, Shekhar Sinha, 
Miriam Woods, C. Ikeocha, F. Mengel, Y. Simon, P. Pearce, S. McKetta and J. Jeffers, 2011 : Understanding and Predicting Fayetteville Shale Gas Production Through Integrated Seismic-to-Simulation Reservoir Characterization Workflow. Conference Paper SPE 147226 presented at the SPE Annual Technical Conference and Exhibition, 30 October-2 November 2011, Denver, Colorado, USA.

10) Norton, Mark and Tushingham, Keith, 2011 : Integrating Data Crucial in Shale Plays. The American Oil \& Gas Reporter.

11) Adisornsupawat, Kanitthorn, Chee Phuat Tan, Leo Anis, A. Vantala, R. Juman and Barry Boyce, 2011 : Enhanced Geomechanical Modeling with Advanced Sonic Processing to Delineate and Evaluate Tight Gas Reservoirs. Conference Paper SPE 142813 presented at the SPE Middle East Unconventional Gas Conference and Exhibition, 31 January-2 February 2011, Muscat, Oman.

12) Cipolla, C.L., R. Lewis, S. C. Maxwell and M. G. Mack, 2012 : Appraising Unconventional Resource Plays: Separating Reservoir Quality from Completion Effectiveness. Conference Paper 14677 presented at the International Petroleum Technology Conference, 7-9
要旨

非在来型資源評価と開発の最適化のための技術

マイク ズーバー

有機シェール貯留層は非常に複雑なため, その経済的な 開発には多くの障壁が存在する; たとえば, シェール層の 発見, 分布の把握, スイートスポットの特定, 坑井位置と 坑井間距離の決定, 掘削の最適化, 坑井仕上げや坑井刺激 の効率化, 操業効率の最大化, それと同時に, 環境保全や 法律遵守などである。非在来型貯留層の特質はそれぞれ異 なつており, ひとつのシェール層で成功した手法が必ずし も他のシェール層でも成功するとは限らない。

シェール貯留層を発見し, 評価し, 掘削し, 仕上げ、そ こから炭化水素を生産するためには、はさまざまな技術が 必要とされる。北米での成功事例を見てみると, シェール 層開発を経済的な成功に導くための技術は, 最適な坑井掘 削位置を決定するための技術およびあらゆる面で効率化を 支援し，コストを削減するための技術であるといえる。長 期的な成功を得るために早い段階で確たる決断を下し, 操 業の効率化を図るために, 最適な技術やサービスを注意深 く選択し適用することが必要である。

本ペーパーでは有機シェール貯留層から炭化水素を生産 するために貢献しているさまざまな技術を紹介し, 論評する。 